\title{
Financing Constraints: Determinants and Implications for Firm Growth in Pakistan
}

\author{
Hamna Ahmed* and Naved Hamid ${ }^{* *}$
}

\begin{abstract}
This study has a twofold objective: (i) to investigate the determinants of firm growth, specifically the extent to which finance constrains enterprise growth; and (ii) to explore the determinants of external financial access in Pakistan. External financial access is defined as access to credit through institutional sources such as private commercial banks, nonbank financial institutions, and state-owned banks and agencies. The study uses data from the second round of the Investment Climate Assessment Survey conducted by the World Bank in FY 2007. The methodology entails using an instrumental variable approach to estimate the impact of external financial access on firm growth while employing a probit model to explore the determinants of external financial access. The results suggest the following: First, finance is a binding constraint to firm growth in Pakistan-a 10 percent increase in the working capital financed through external sources is predicted to increase the average annual growth rate by 5.6 percentage points. Second, financial depth is important for access-across the country, access is better where there is greater penetration of financial infrastructure. Third, a range of internal factors such as size, export status, quality of human capital, and organizational form emerge as important determinants of external financial access in Pakistan.
\end{abstract}

Keywords: Financial Access, Firms, Financial Depth, Pakistan.

JEL Classification: 043, C36.

\section{Introduction}

This study has a twofold objective: (i) to investigate the determinants of firm growth, specifically to study the extent to which finance constrains enterprise growth; and (ii) to explore the determinants of external financial access in Pakistan.

\footnotetext{
* Research and Teaching Fellow, Centre for Research in Economics and Business, Lahore School of Economics.

*** Director, Centre for Research in Economics and Business, Lahore School of Economics.
} 
For the purpose of this study, external financial access is defined as access to credit through institutional sources such as private commercial banks, nonbank financial institutions, and state-owned banks and agencies. Subsequently in this article, the terms "external credit," "formal credit," and "credit through financial institutions" are used interchangeably.

The study uses data from the second round of the Investment Climate Assessment (ICA) Survey conducted by the World Bank in the fiscal year (FY) 2007. The dataset provides detailed information on firmspecific characteristics as well as a wide range of investment climate variables pertaining to infrastructure and services, courts, crime, government-business relations, degree of competition, and factor markets, i.e., land, labor, and finance.

The remainder of the article is organized as follows. Section 2 develops the backdrop and outlines the motivation behind the study. Section 3 provides a brief review of the literature on finance and growth. Section 4 describes the data used and offers some basic statistics for the overall sample and for the determinants of firm growth and external financial access for the sample of firms under study. Section 5 discusses the methodology and empirical framework. Section 6 presents the results, and Section 7 concludes the study.

\section{Motivation}

Finance is an important pillar of growth. This finding has been corroborated both at the macro and micro-level. The argument that financial development and economic growth are positively correlated dates back to Schumpeter (1911), and has been confirmed by various subsequent studies such as Goldsmith (1969), King and Levine (1993), Levine and Zervos (1998), and Robinson (1952), among others. At the micro-level, financing constraints are predicted to exert a negative influence on firm growth (Ayyagari, Demirgüç-Kunt, \& Maksimovic, 2008; Beck, Demirgüç-Kunt, \& Maksimovic, 2005). For instance, Beck et al. (2005) find in a cross-country sample that firms that report finance as a major constraint bear a growth penalty of 3 percent compared to firms that do not report finance as an obstacle.

The constraint to financial access and its impact on growth is considered most severe for small and medium enterprises (Beck \& Demirgüç-Kunt, 2006; Beck et al., 2005). For a sample of firms in eastern Europe, employment growth was found to be 9 percent higher while 
revenue growth was 36 percent higher in firms with access to credit from financial institutions between 2002 to 2005 (World Bank, 2009, p. 91). For Pakistan, a decomposition of total factor productivity reveals that, among different investment climate variables, finance accounts for 17 percent of both average and aggregate productivity. ${ }^{1}$

Financial markets in Pakistan are underdeveloped relative to other developing countries. With credit to the private sector at 23.5 percent of gross domestic product (GDP) in 2009, Pakistan ranks lowest not only compared to other South Asian countries such as India (46.8 percent) and Bangladesh (41.5 percent), but also in comparison with other developing countries (World Bank, 2011) (Figure 1). A look at the sources of working capital finance reveals that a similar trend prevails at the micro-level. The average percentage of working capital financed through commercial banks is extremely low (6.5 percent) compared to other South Asian countries such as Bangladesh (32 percent), Sri Lanka (21 percent), and India (16 percent) (Figure 2).
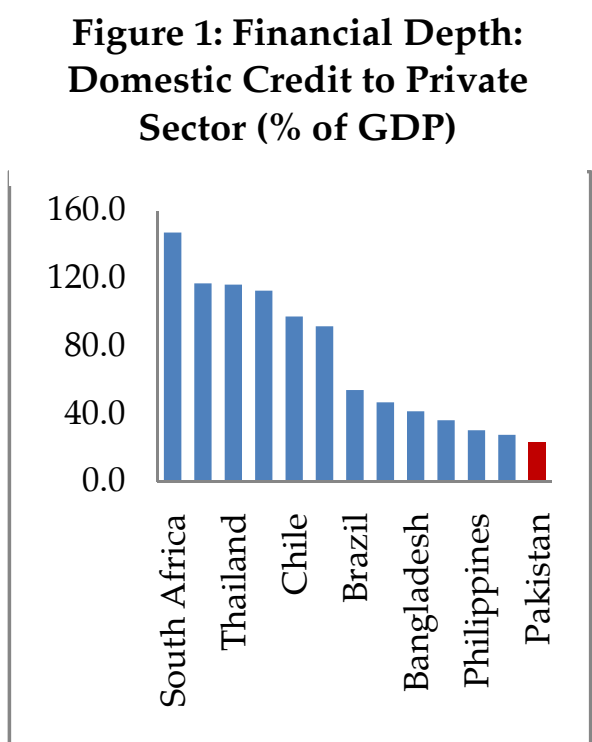

Source: World Bank, World Development Indicators, 2011.

\section{Figure 2: Commercial Banks' Share of Working Capital Finance $(\%)$}

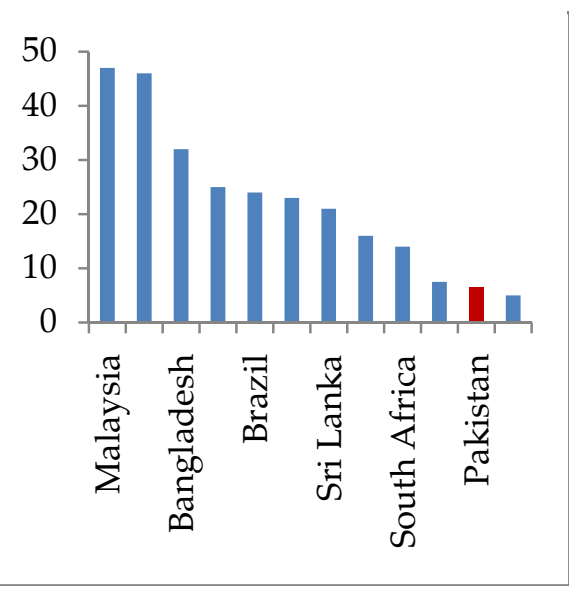

Source: World Bank, Various rounds of Investment Climate Assessment Surveys.

Moreover, within the sample under study, almost 83 percent of working capital is financed through internal funds and retained earnings, while a mere 7 percent is financed through external credit. That financial

\footnotetext{
1 “Average" refers to the sample average productivity, and "aggregate" refers to the weighted average productivity, with weights equal to the share of a firm's sales in the sample.
} 
deepening in Pakistan is low also comes across when comparing perceptions of managers in Pakistan on the severity of finance as a growth constraint vis-à-vis perceptions of managers in other developing countries. Pakistan ranks third-highest with almost 40 percent of firms reporting finance as a major or severe obstacle to growth whereas the number for other developing countries is much lower (Figure 3).

\section{Figure 3: Access to Finance as a Constraint to Firm Growth (\%)}

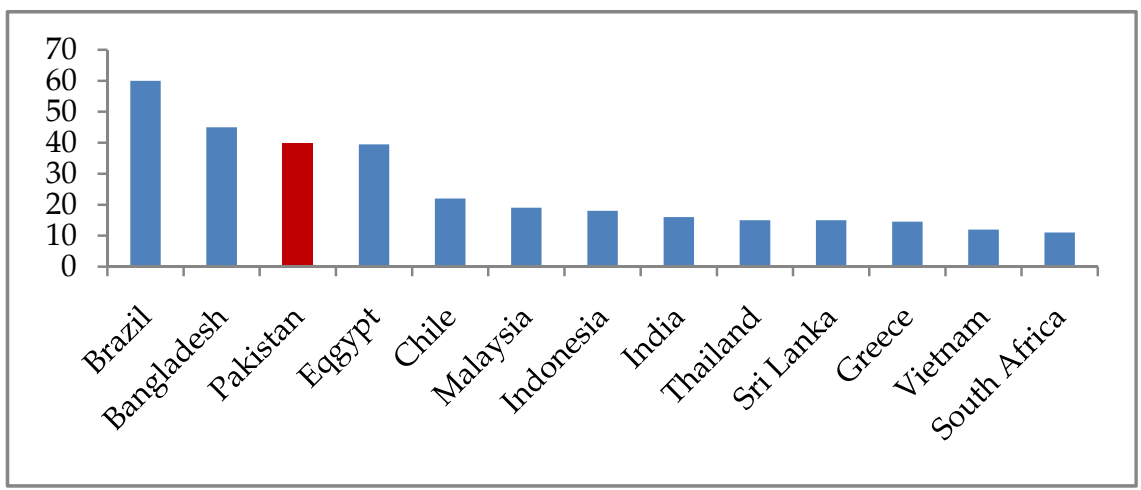

Source: World Bank, Various rounds of Investment Climate Assessment Surveys.

The period covered is interesting for studying the link between finance and firm growth in Pakistan. We examine firm growth between 2003 and 2006, a period marked by abundant credit availability and fairly low interest rates. In other words, 2003-06 can be thought of as a best-case scenario for ease of financial access, and the results on the growth penalty of limited financial access for manufacturing firms can be considered to be at the lower end.

Today, the situation is very different. The economic environment is plagued by uncertainty, rising nonperforming loans, and excessive public sector borrowing, which has crowded out private sector credit. Moreover, with a tight monetary policy to rein in inflation, the severity of the financing constraint for private sector businesses has become magnified. In this context, the study helps shed light on the likely microeconomic consequences of the current macroeconomic policies.

\section{Literature Review}

The debate on the link between finance and economic growth dates back to Schumpeter (1911), and has both a macro and micro-dimension. 
At the macro-level, financial sector development is predicted to have a positive impact on growth and per capita income (Schumpeter, 1911). For a cross-country sample of 35 countries, Goldsmith (1969) finds that financial development is consistent with periods of high economic growth. King and Levine (1993) find that high levels of financial development are associated with rapid economic growth, physical capital accumulation, and improvements in economic efficiency for a crosscountry sample spanning over 80 countries. This hypothesis is also confirmed by Levine and Zervos (1998) who argue that the development of financial markets and intermediaries has an important bearing on growth.

While these studies emphasize the statistically significant impact of financial development on growth, there are others that are skeptical of the direction of causality between financial sector health and growth. For instance, Robinson (1952) argues that financial development is a natural consequence of economic acceleration rather than a predictor of growth. Following suit, Lucas (1988) contends that the link between finance and growth is overemphasized.

At the micro-level, the emphasis is on how the lack of finance can hamper enterprise growth. The main intuition underlying the growthfinance link at the micro-level is that greater financial development makes it easier to raise external finance. This, in turn, eases finance constraints, especially for small and medium firms because their ability to raise internal capital is limited. Firms are thus able to invest in profitable growth opportunities. In this manner, greater financial access serves as a catalyst for growth.

Demirgüç-Kunt and Maksimovic (1998) find that market imperfections - such as underdeveloped financial and legal systemslimit a firm's ability to raise long-term external finance. This, in turn, inhibits the firm's investment and growth potential.

Based on a sample of US manufacturing firms, Rajan and Zingales (1998) find that industries that depend more on external finance are likely to grow faster in countries that ex ante have better developed financial markets. This is made possible for two reasons: (i) financial development reduces the cost of raising external finance, and (ii) it creates a disproportionately favorable environment for young firms that would otherwise find it more difficult to raise capital. 
Later work by Beck et al. (2005) also supports this claim. For a cross-country sample of firms, they find that financial and legal constraints, as well as corruption, have an adverse impact on firm growth. This relationship, however, varies by firm size. The authors find that the growth of small firms tends to be most severely constrained by financing issues compared to larger firms. The impact of financial and legal constraints on firm growth tends to be strongest for small firms.

Ayyagari et al. (2008) investigate the importance of financing constraints relative to other business environment obstacles to firm growth for a sample of 4,197 firms from 80 different developed and developing countries. The authors find that finance, policy instability, and crime are the only binding constraints to firm growth. All other features of the business environment-corruption, taxes and regulations, judicial efficiency, and anti-competitive practices, etc.- have either an insignificant or indirect impact on growth, which works through the binding constraints channel.

An important channel through which access to finance promotes growth is that of fostering innovation. For a sample of 10,000 firms from 34 developing countries, Ayyagari, Demirgüç-Kunt, \& Maksimovic (2007) show that firms with greater access to external finance are also more innovative and dynamic. Innovation is measured by the firm's ability to introduce new products and processes. Dynamism, on the other hand, is defined by activities such as the "opening of a new plant, bringing inhouse previously out-sourced activities, and establishing foreign joint ventures and new licensing agreements" (Ayyagari et al., 2007).

This article contributes to the micro-level literature on finance and firm growth. Two main features of this study distinguish it from existing studies on the topic. Recognizing simultaneity in external financial access and firm growth, we employ an instrumental variable approach and construct a unique exogenous measure of access that incorporates both demand and supply-side influences on financial access. Further details on this are discussed in Section 5. In addition, this is the first study to explore simultaneously the determinants of firm growth and external financial access for Pakistan. This will be useful in providing an in-depth and holistic picture of the finance-firm growth nexus for manufacturing firms in Pakistan. 


\section{Data}

The study uses data from the second round of the Pakistan ICA-II Survey conducted by the World Bank in 2006/07. The ICA-II survey provides detailed information on firm characteristics and various aspects of the business environment in the country. The former includes information on an establishment's sales, employment, and productivity. Key dimensions of the business environment include infrastructure and services, courts, crime, government-business relations, degree of competition, and factor markets (land, labor, and finance).

The sampling frame consists of a stratified random sample of firms drawn from the Census of Manufacturing Industries (2005), the only firm-level survey available in Pakistan and conducted by the Federal Bureau of Statistics. The total sample was based on 1,350 firms of which 1,186 are manufacturing establishments while the rest are service firms. The sample is representative at the national, provincial, and sectoral level. The analysis in this paper is limited to manufacturing firms only.

The surveyed firms are located in 13 cities across the country with a large share coming from big cities such as Karachi, Lahore, Faisalabad, etc. (Figure 4). ${ }^{2}$ The firms belong to nine different industries of which a 50 percent come from the textiles, food, and garments industries (Figure 5). Another one third has been grouped together in the "others" category, and consists of firms that produce products such as sports goods, surgical instruments, cutlery, furniture, jewelry, shoes, plastics, and pharmaceutical goods, etc.

\footnotetext{
${ }^{2}$ For the rest of the paper, firms in Hub have been pooled with those in Karachi. Hub has not been treated as a separate location for two reasons: (i) in terms of access to finance, conditions are similar to those faced by firms in Karachi because it lies on the outskirts of the city, with most nonproduction staff being based in Karachi; (ii) only six firms out of a total sample of 1,186 have been surveyed from this location.
} 


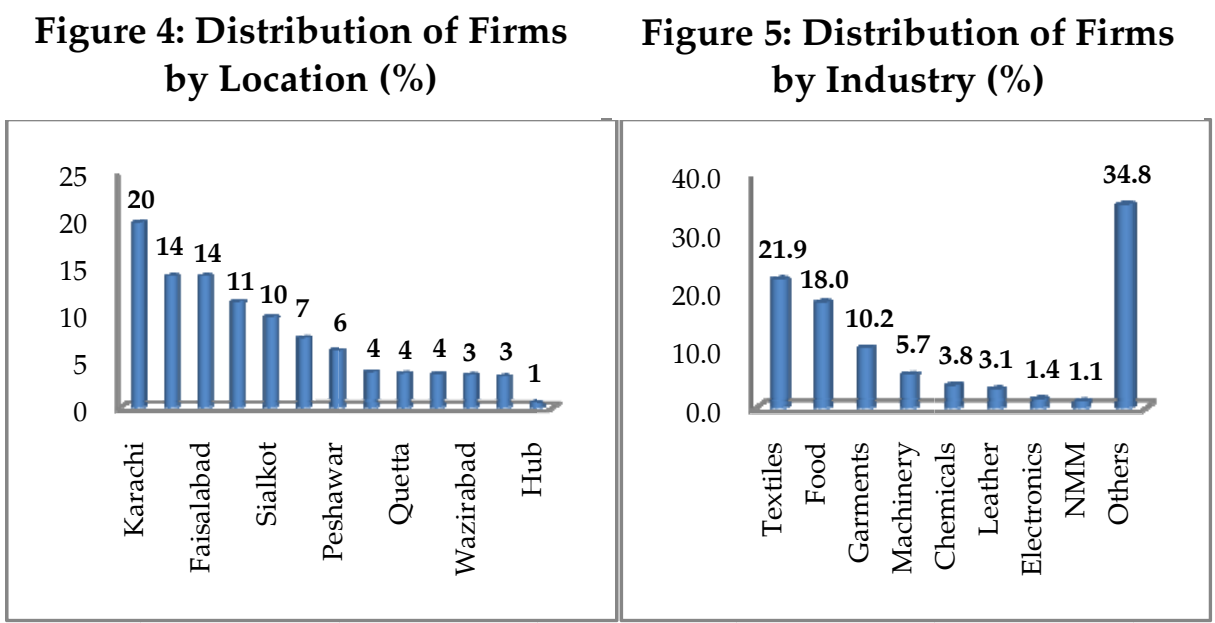

Source: World Bank, Investment Climate Assessment Survey, 2007.

A firm is classified as small if it employs fewer than 20 workers, medium if it employs 20-100 workers, and large if it employs 100 workers or more. About 50 percent of the sample consists of small firms while the rest are either medium or large (Figure 6). Large firms are predominantly located in large cities; Karachi and Lahore alone account for 63.5 percent of all large firms in the sample as compared to 18.6 and 35.3 percent of small and medium firms, respectively. A third of all small firms are located in Sialkot, Gujranwala, and Faisalabad (Table A1 in the Annexure).

The inter-industry size distribution shows that 60 percent of all large firms belong to three industries: textiles, food, and garments. The intra-industry size distribution on the other hand reveals that leather and machinery/equipment manufacturing firms are predominantly small.

One fifth of the surveyed firms export directly. The share of exporting firms increases to 30 percent when indirect exporters are also included (Figure 7). 
$\begin{array}{cc}\text { Figure 6: Distribution of Firms by } & \text { Figure 7: Distribution of Firms by } \\ \text { Size } & \text { Export Status }\end{array}$

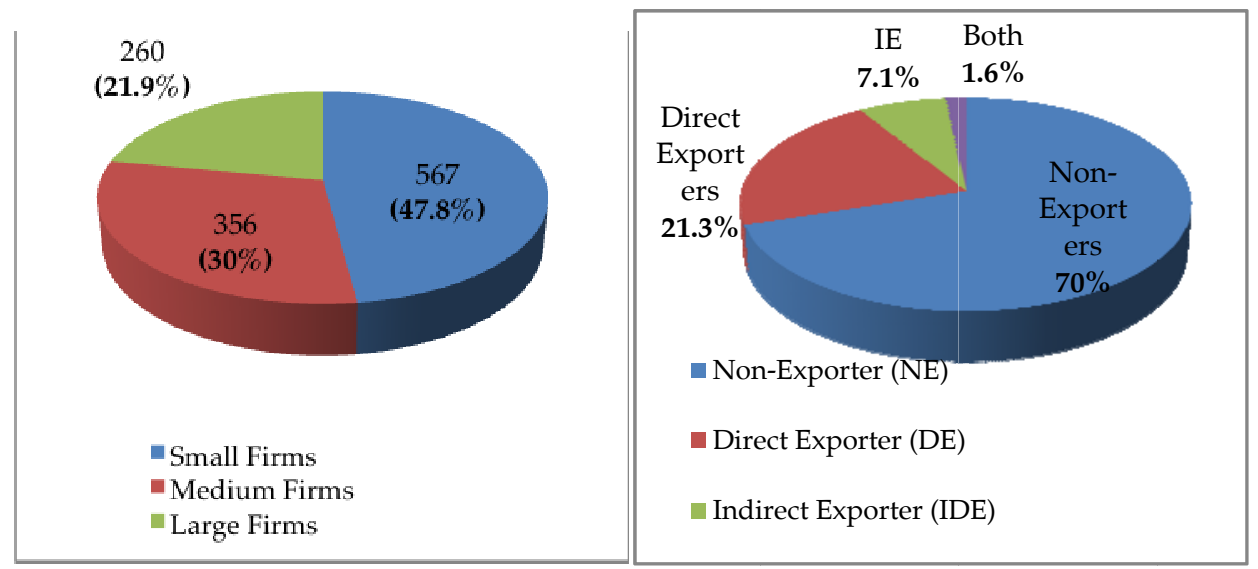

Source: World Bank, Investment Climate Assessment Survey, 2007.

\section{Access to Finance}

Of the total sample, only 14.7 percent of the firms have access to external finance. Large firms are six times more likely to have access than small firms (Figure 8). Small firms have easier access to external finance in locations where there are predominantly small or medium firms-such as Wazirabad-and in cities where firms are part of a cluster, such as Sialkot and Gujranwala (Tables A1 and A2 in the Annexure). Being a small firm in metropolitan cities such as Karachi, Lahore, or Faisalabad comes with a penalty; for instance, small firms are 18 times less likely to have access than large firms in Karachi, but only four times less likely to have access in Gujranwala. This could imply either that banks are more likely to lend to small firms when competition from large firms is limited, or that it is easier to access finance when firms are part of a network.

Figure 8: Financial Access by Size (\%)

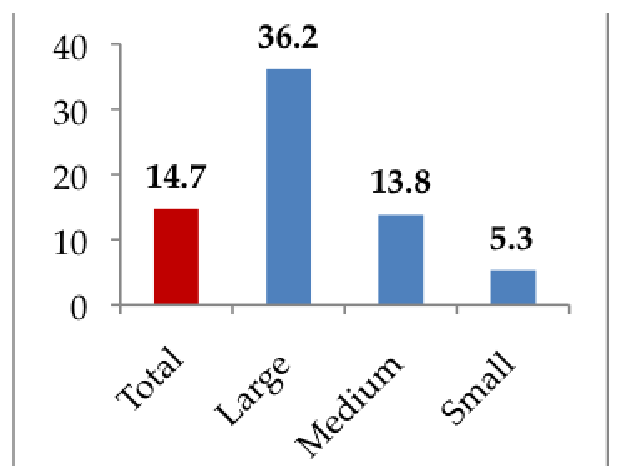

Source: Authors' calculations; World Bank, Investment Climate Assessment Survey, 2007. 
The correlation between size and external financing is also evident from intra-industry patterns of financial access (Table A3 in the Annexure). For almost all industries, financial access increases substantially from small to large firms.

Between exporters and nonexporters, direct exporters are more likely to have access. On average, a direct exporter is three times more likely to have access than a nonexporter (Table 1). This is also true for each size category. The advantage of access, however, systematically falls from small to large firms; a small direct exporter is eight times more likely to have access than a small nonexporter while a large exporter is only 1.5 times more likely to have access than its nonexporting counterpart.

This could imply either that, ex ante, more productive firms selfselect themselves into becoming exporters, or that, ex post, exporting firms are more productive (Wagner, 2007). Irrespective of which way the causality runs, a firm's export status seems to have a bearing on its ability to access external finance for the sample of firms under study. It is worth noting that being an indirect exporter does not significantly improve access to finance. This is an indication of the lack of documentation in domestic commerce and the failure of government policies aimed at providing indirect exporters with the same incentives as direct exporters.

\section{Table 1: Firms with External Financial Access by Exporting Status}

\begin{tabular}{lccc}
\hline \multicolumn{1}{c}{ Size } & Direct Exporters (\%) & Indirect Exporters (\%) & Nonexporters (\%) \\
\hline Small & 24.0 & 5.6 & 3.4 \\
Medium & 21.1 & 10.5 & 12.1 \\
Large & 43.9 & 33.3 & 28.6 \\
Total & 33.3 & 14.3 & 9.3 \\
\hline
\end{tabular}

Source: Authors' calculations; World Bank, Investment Climate Assessment Survey, 2007.

Finally, there are a number of other differences between firms with access and those without access (Table 2). Firms with access are more advanced technologically; twice as many machines are computercontrolled compared to the sample of firms without access. They are three times more likely to innovate by introducing new products and processes than their counterparts without access. Moreover, firms with access have better-quality human capital. In general, the top management in firms with access is more experienced and has attained a higher education level than their counterparts without access. Also, these firms are mostly organized as private limited or publicly listed companies as compared to 
firms without access, of whom 78 percent are sole proprietorships or partnerships.

Table 2: Characteristics of Firms by Financial Access

\begin{tabular}{lcccc}
\hline \multicolumn{1}{c}{ Variable } & \multicolumn{2}{c}{ Firms with Access } & \multicolumn{2}{c}{$\begin{array}{c}\text { Firms without } \\
\text { Access }\end{array}$} \\
\cline { 2 - 5 } & $\mathrm{N}$ & $(\%)$ & $\mathrm{N}$ & $(\%)$ \\
\hline $\begin{array}{l}\text { Human capital } \\
\begin{array}{l}\text { Top manager < undergraduate } \\
\text { degree }\end{array}\end{array}$ & 23 & 13.2 & 537 & 53.1 \\
$\begin{array}{l}\text { Top manager = undergraduate } \\
\text { degree }\end{array}$ & 79 & 45.4 & 311 & 30.7 \\
Top manager = postgraduate degree & 72 & 41.4 & 161 & 15.9 \\
\hline $\begin{array}{l}\text { Organizational form } \\
\text { Sole proprietorship/partnership }\end{array}$ & 74 & 42.5 & 786 & 77.7 \\
$\begin{array}{l}\text { Private limited } \\
\text { Publicly listed }\end{array}$ & 77 & 44.3 & 179 & 17.7 \\
\hline $\begin{array}{l}\text { Innovation } \\
\text { New product }\end{array}$ & 23 & 13.2 & 38 & 3.8 \\
New process & 51 & 29.3 & 131 & 12.9 \\
\hline
\end{tabular}

Source: Authors' calculations; Investment Climate Assessment Survey, 2007.

\section{Growth}

On average, firms in the sample grew at 4.3 percent per annum from 2003 to 2006. The growth rate was much higher for firms with access (7 percent) compared to firms without access (3.9 percent) (Figure 9a). Moreover, growth rates are different across cities and across industries (Figures $9 b$ and 9c). 
Figure 9: Average Annual Growth Rate, 2003-06 (\%)

(a) Overall and by

Financial Access

(b) By Industry

(c) By Location

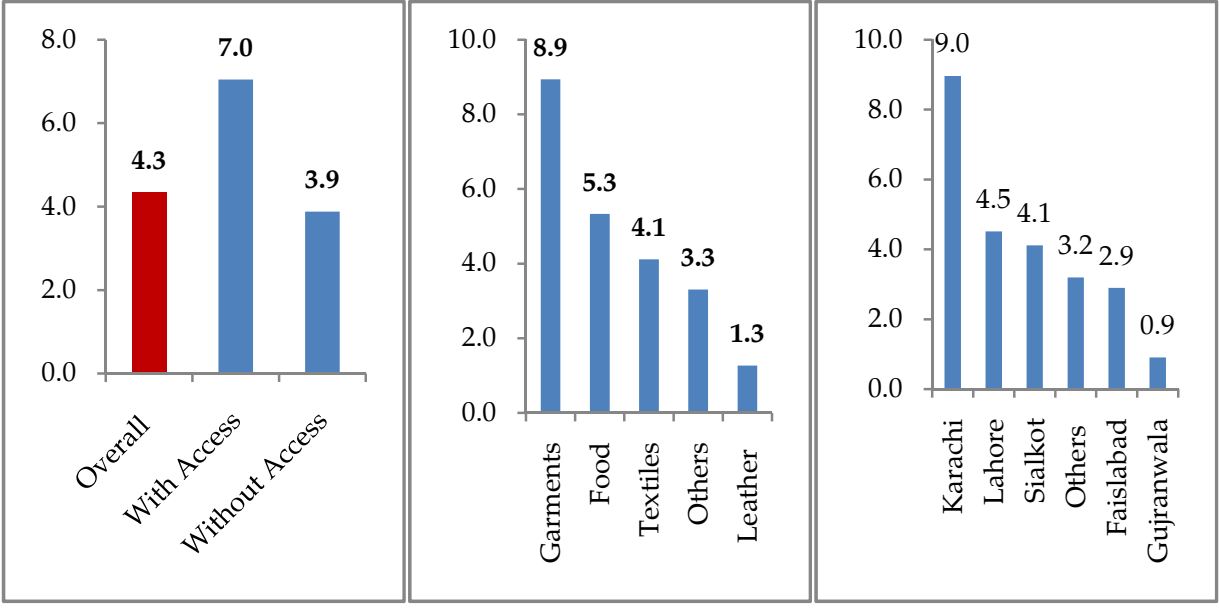

Source: Authors' calculations; World Bank, Investment Climate Assessment Survey, 2007.

In light of these descriptive statistics, we can draw three broad conclusions regarding the determinants of firm growth and external financial access: First, access is a clear divide and that finance is an important aspect of growth. Second, firms with access are inherently different with regard to their organizational form, quality of human capital, and degree of innovation from firms without access. Third, size, export status, industry, and location appear to be important dimensions of access. In what follows, these claims will be tested more rigorously using quantitative techniques.

\section{Methodology}

\subsection{Determinants of Firm Growth}

The observations in the last section are based on a casual glance at the data and warrant more rigorous quantitative treatment. To that end, the regression model is specified as follows:

$$
\begin{aligned}
& G R_{f i l}=\gamma+\beta_{1} A_{f i l}+\sum_{m=2}^{n} X_{f i l} \beta_{m}+\sum_{i=1}^{8} I_{i} \alpha_{i}+\sum_{l=1}^{12} L_{l} \delta_{l}+\varepsilon_{f i l} \\
& \varepsilon_{f i l}=v_{i}+\tau_{l}+\mu_{f i l}
\end{aligned}
$$

where $G R_{\text {fil }}$ measures the average annual labor growth rate of firm $f$, industry $i$, location $l$ between fiscal year 2003 to 2006 . 
$A_{\text {fil }}$; financial access to formal credit for each firm $f$ in industry $i$ and location $l$. For the dataset under study, financial access to formal credit could have potentially been measured in three ways: (i) as a percentage of the working capital financed through institutional sources in the past year, (ii) as a percentage of new investments financed through institutional sources in the past year, and (iii) in terms of the firm manager's perceptions of the severity of the "access to finance" constraint (i.e., availability and cost of formal credit, interest rates, fees, and collateral requirements) as an obstacle to the firm's current operations.

The data on item (iii) was noisy because responses were based on perceptions rather than actual availability. For instance, while a firm may be financially constrained, managers might not perceive access to finance as a major obstacle to growth relative to other constraints that the firm might face at a particular point in time. Similarly, formal credit may be readily available to a firm, but managers might perceive access to finance as a major obstacle due to a poor working relationship between the establishment's management and that of the financial institution. Using item (ii) as a proxy for financial access was also problematic as only 237 out of a total of 1,168 firms reported having undertaken any new investment over the past year. Using this measure would have thus meant a huge loss in sample size, which would have affected the quality of results. For reasons of data availability, the percentage of working capital financed through institutional sources was used as a proxy for access to formal credit. Institutional sources included private commercial banks, nonbank financial institutions, and state-owned banks or agencies.

Apart from reasons of data availability, the financing of working capital through formal credit serves as a good proxy for financial access (or the lack thereof) in Pakistan's context. This is because the main source of credit in Pakistan is the banking sector, which provides funding largely in the form of working capital. In most cases, even investment (except for green-field projects or major capacity expansion) is financed through lines of credit and short-term loans, which are automatically rolled over on maturity.

$X$ is a vector of firm-specific characteristics. Broadly, these characteristics pertain to four main categories: (i) the general topography of the firm as given by its size and export status, (ii) the quality of its human capital, (iii) its organizational form, and (iv) degree of innovation. I is a vector of industry dummies while $L$ is a vector of location dummies to account for industry and region fixed effects (see Table A4 in the Annexure for 
more details on which variables are included under each head and how they have been constructed). $\gamma, \beta, \alpha$ and $\delta$ are unknown parameters to be estimated from the regression model. Finally, $\mathcal{E}$ is a normally distributed error term comprising three components as illustrated in Equation 1.2. $\left(\mu_{f i l}\right)$ represents all unobserved firm-specific characteristics that might affect a firm's growth rate.

The key identification condition required to produce an unbiased estimate of the impact of financial access on firm growth using an ordinary least squares (OLS) estimation technique is given by:

$$
\operatorname{Cov}(A, \mathcal{E})=0
$$

This identification condition is, however, violated by the presence of endogeneity bias in the variable of interest, i.e., financial access. Firms with access may find it easier to expand and invest in profitable opportunities, and this will in turn spur growth. However, a firm's growth rate may have an impact on the probability of it being able to access finance, and financial institutions may be more willing to lend to rapidly growing firms with a sound cash-flow position. This reverse causality between financial access and growth leads to endogeneity bias and hence violates the key identification condition outlined in Equation 1.3. Applying the OLS method with an endogenous variable of interest will produce a biased and inconsistent estimate of the impact of financial access on growth.

\section{An Exogenous Measure of Financial Access}

We use an instrumental variable approach to account for endogeneity. The degree of financial access available to a firm is likely to be a function of both demand and supply-side factors. For instance, Rajan and Zingales (1998) use an interaction term in which the demand side is captured by calculating each industry's technological demand for external finance while the supply side is measured by the level of financial development in the country. To account for this, we construct an instrumental variable such that it is an interaction term between demand and supply-side variables.

On the demand side, it is argued that some firms may be more dependent on external finance than others. This could be because of differences in the scale of the project, in the product's gestation period, or in the requirement for continuing investment (Rajan \& Zingales, 1998). 
One possibility is to use a firm-level measure of external financial dependence. For instance, Hyytinen and Toivanen (2005) use profitabilitybased measures: a firm is classified as dependent on external finance if its return on assets was negative in the last FY or if the entrepreneur responded in the survey that the firm's current profitability was worse than its average performance over the last three years. Poor profitability would imply the availability of a low level of internal finance and hence a greater dependence on external finance. The drawback of using a firm-level measure, however, is that reverse causality would persist between growth and financial dependence, thus biasing the results.

To account for this limitation, the study uses an aggregate measure of external financial dependence at the industry level. To that end, information on bank advances as a ratio of total value added is used as a proxy for an industry's dependence on external finance. To capture the supply side, a distinction is made between "availability" of external financial credit and banks' "willingness" to provide that credit. The level of local financial development-as measured by the number of bank branches in the city in which the firm is located-is used as a proxy for "availability." "Willingness" is measured by the percentage of firms that have access to external finance in a particular firm's size category (see Table A4 in the Annexure for details of data sources for each of these indicators).

For this interaction term to be a valid instrument of firm-level external financial access, the following conditions must hold:

$$
\begin{aligned}
& \operatorname{Cov}(I, A) \neq 0 \\
& \operatorname{Cov}(I, G R)=0
\end{aligned}
$$

where $I$ represents the instrumental variable, $A$ is access, and $G R$ is the growth rate, the dependent variable. A fairly high correlation between $A$ and $I$ (27.9 percent) and fairly low correlation between GR and $I$ (0.08 percent) support the use of this interaction term as an appropriate instrument for firm-level external financial access.

If conditions 1.4 and 1.5 are satisfied, Equation 1.1 can be estimated in two stages. The first stage entails specifying a reduced-form equation forwhich is a function of $I$ as well as all other exogenous variables. This equation is given by:

$$
A_{f i l}=\pi_{0}+\pi_{1}\left(F D_{l} * \alpha_{f s} * D_{i}\right)+\sum_{m=2}^{n} \pi_{m} Z+\mu_{f i l}
$$


where the term in parenthesis represents the instrumental variable; $F D_{l}$ is financial depth in location $l ; \alpha_{f s}$ represents percentage of firms with external financial access in firms' size category $s$; while $D_{i}$ measures industry $i$ 's dependence on external finance. $Z$ is a vector of firm specific characteristics, as well as industry and location dummies. The second stage involves estimating (1.1) after replacing $(A)$ with its fitted values obtained from (1.6).

The second stage involves estimating Equation 1.1, having replaced with its fitted values obtained from Equation 1.6.

\subsection{Determinants of Financial Access}

In the next step, we specify the following regression model to explore the determinants of financial access:

$$
\begin{gathered}
\operatorname{Prob}\left(A_{\text {fil }}=1 \mid F D, C, G R, X, I, L\right)=\gamma+\beta_{1} F D_{l}+\beta_{2} C_{f}+\beta_{3} G R_{i}+ \\
\sum_{m=4}^{n} X_{f i l} \beta_{m}+\sum_{i=1}^{\varepsilon} I_{i} \alpha_{i}+\sum_{l=1}^{12} L_{l} \delta_{l}+\varepsilon_{f i l}
\end{gathered}
$$

where $A_{f i l}$ is a dummy variable equal to 1 if firm $f$ in industry $i$ and location $l$ has access to external finance and 0 otherwise. $F D_{l}$ is a measure of financial depth proxied by number of bank branches in city $l$. $C_{f}$ is the business climate index based on perceptions of firm $f^{\prime \prime}$ s manager. $G R_{i}$ is the average annual growth rate between 2003 to 2006 of industry $i$. Refer to Table 4, Appendix A for more details on how the variables have been constructed. $X i$ is a vector of firm specific characteristics, $I_{i}$ a vector of industry dummies while $\mathrm{L}_{i}$ is a vector of location dummies to control for industry and region fixed effects.

\section{Results}

\subsection{Determinants of Firm Growth}

Our results reveal that a range of internal and external factors are important determinants of firm growth in Pakistan (Table 3). 
Table 3: Determinants of Firm Growth in Pakistan

\begin{tabular}{|c|c|c|}
\hline Variable & Coefficient & P Value \\
\hline External access & $0.56^{* *}$ & 0.03 \\
\hline \multicolumn{3}{|l|}{ Type of firm } \\
\hline Small or medium enterprise & -0.02 & 0.90 \\
\hline Export status & -0.04 & 0.39 \\
\hline \multicolumn{3}{|l|}{ Organizational form } \\
\hline Private limited & -0.03 & 0.42 \\
\hline Publicly listed & -0.04 & 0.56 \\
\hline \multicolumn{3}{|l|}{ Innovation } \\
\hline New process & $0.12^{*}$ & 0.01 \\
\hline New product & 0.00 & 0.97 \\
\hline \multicolumn{3}{|l|}{ Human capital } \\
\hline Experience & 0.00 & 0.15 \\
\hline Undergraduate degree & 0.01 & 0.80 \\
\hline Postgraduate degree & 0.00 & 0.97 \\
\hline More than 13 years' education ${ }^{3}$ & -0.02 & 0.86 \\
\hline \multicolumn{3}{|l|}{ Business environment } \\
\hline Business climate index & 0.01 & 0.26 \\
\hline \multicolumn{3}{|l|}{ Location dummies } \\
\hline Sheikhupura & $-0.091^{* *}$ & 0.02 \\
\hline Faisalabad & $-0.085^{* * *}$ & 0.06 \\
\hline Gujranwala & $-0.141^{*}$ & 0.00 \\
\hline Wazirabad & $-0.116^{* * *}$ & 0.08 \\
\hline Sukkur & $-0.081^{* *}$ & 0.05 \\
\hline \multicolumn{3}{|l|}{ Industry dummies } \\
\hline Chemicals & $-0.101^{* *}$ & 0.05 \\
\hline Constant & $3.538^{*}$ & 0.00 \\
\hline $\mathrm{N}$ & 1,142 & \\
\hline
\end{tabular}

*** Significant at $1 \%,{ }^{* *}$ significant at $5 \%,{ }^{*}$ significant at $10 \%$.

$\wedge$ Only the significant location and industry dummies have been reported.

Source: Authors' calculations.

The impact of financial access on firm growth is positive and statistically significant. The instrumental variable estimate of the impact of financial access suggests that a 10 percent increase in working capital

3 The model was also run with the dummy variable equal to 1 if a typical production worker has attained more than six years of education, with no change in results. 
financed through external sources will increase a firm's growth rate by 5.6 percentage points, ceteris paribus. Thus, it is evident that the lack of external financial access imposes a substantial growth penalty on Pakistani firms. This finding is in line with the literature, with estimates for the growth penalty ranging from 3 to 9 percent in the studies referred to earlier.

Innovation also turns out to be positively related to growth. Firms that had introduced a new process in the last three years had a 12 percenthigher average annual growth rate. However, one must be wary of causal interpretation given the issue of simultaneity. High-growth firms may have more available resources to undertake research and development, and thus more likely to innovate. This finding is also consistent with the literature on innovation, productivity, and growth. Ranging from early studies by Solow in which technical progress is treated as an exogenous factor-to studies that fall within the ambit of new growth theory-where technical progress or innovation is treated as endogenous - the consensus seems to be that innovation has a significant effect on productivity at the level of the firm, industry, and country.

Other firm-specific characteristics such as size, organizational form, human capital, and export status are not directly related to growth, but they do have an indirect effect that works through the finance channel (see Section 6.2 for further discussion).

The lack of significance of export status for firm growth is a finding that warrants some discussion. The literature predicts a positive relation between exports and productivity either because more productive firms self-select themselves into becoming exporters or because of the learning-by-exporting hypothesis whereby knowledge flows from international buyers and competitors and improves firms' post-entry performance. In Pakistan's case, at least for this particular period, export status seems to have no effect on firm growth. This could partly be because export firms are concentrated in products such as food, garments, and textiles, which rank at the low end of the technology ladder. The possibilities of learning-by-doing and positive spillovers are limited, and most firms may not be accruing the growth benefits of their presence in export markets. 
On the external side, a firm's location is significant for its growth. Compared to big cities, firms in smaller cities have lower growth rates. 4 For instance, as Table 3 illustrates, the growth rate differential between firms in Karachi and other smaller cities such as Sheikhupura, Gujranwala, Wazirabad, and Sukkur ranges between 8.1 and 14.1 percent.

Business climate, however, is insignificant for firm growth. This would have been surprising in the case of a cross-country study, but in this study, it is possible that our location dummies capture the impact of the business climate. To explore this further, we estimate the following equation:

$$
C_{f i l}=\pi_{0}+\sum_{l=1}^{12} L_{l} \delta_{l}+\varepsilon_{f i l}
$$

where $C_{f}$ is the business climate index, based on perceptions of firm $f^{\prime}$ 's manager in industry $i$, and location $l$. The index ranges between 0 and 13, with greater the number of dimensions of business environment that the managers perceive to be major obstacles for firm's operations, higher the value of the index. $\mathrm{L} l$ on the other hand is a vector of location dummies, while $\varepsilon_{f i l}$ is the error term. The omitted category is Karachi. Results show that it is not that business climate does not matter but, as suspected, the location dummies are picking up differences in business climate across cities. This is evident from the fact that 8 out of 12 locations emerge as statistically significant (Table 4). Also, it is interesting to note is that managers perceive business environment in Lahore to be better than that in Karachi, while in all other cities, managers consider business environment to be worse than Karachi.

\footnotetext{
${ }^{4}$ For the results in Table 3, Karachi is used as the omitted category. The finding also holds true when Lahore is made the omitted category. In this case, the growth rate differential between firms in Lahore and other smaller cities ranged between 8 and 20 percent.
} 
Table 4: Business Climate and Location

\begin{tabular}{lcc}
\hline Dependent variable: Business climate & & \\
\hline City & Coefficient & P Value \\
\hline Lahore & $-1.07^{* * *}$ & 0.00 \\
\hline Sheikhupura & $3.97^{* * *}$ & 0.00 \\
Faisalabad & $2.99^{* * *}$ & 0.00 \\
Gujranwala & $1.20^{* * *}$ & 0.00 \\
Wazirabad & $1.67^{* * *}$ & 0.00 \\
Rawalpindi/Islamabad & $3.04^{* * *}$ & 0.00 \\
Hyderabad & $1.58^{* * *}$ & 0.00 \\
Quetta & $1.32^{* * *}$ & 0.01 \\
\hline Sialkot & 0.29 & 0.32 \\
Sukkur & -0.67 & 0.25 \\
Peshawar & 0.01 & 0.99 \\
\hline
\end{tabular}

*** Significant at $1 \%$.

Source: Authors' calculations.

\subsection{Determinants of External Financial Access}

The study's results reveal that a range of both internal and external factors are important in determining external financial access in Pakistan (Table 5).

On the external side, the level of financial depth in the city as well as the firm's location is significant, while industrial growth is insignificant for access. A 1 percent increase in the number of bank branches in the firm's city of location increases its probability of access to external finance by 4.9 percent, ceteris paribus. Compared to firms located in metropolitan cities such as Karachi, Lahore as well as those located in export-led hubs such as Sialkot, firms in all other cities have a lower probability of access. ${ }^{5}$ The results show that the access differential between firms in Karachi and other smaller cities ranges between 4.9 and 13.1 percent.

An establishment's growth rate, on the other hand, is insignificant for access. To account for reverse causality, the model was also estimated using industry-level growth rate averages, for which the finding continued to hold

\footnotetext{
${ }^{5}$ For the results in Table 5, Karachi is used as the omitted category. The model was also run using different omitted categories, i.e., Lahore and Sialkot. The result holds true in each case. With Lahore (Sialkot) as the omitted category, the access differential ranged between 9 and 20 percent (8 to 15 percent).
} 
true. This is not surprising given the nature of bank lending in Pakistan whereby banks prefer short-term securities (State Bank of Pakistan, 2010, p. 15). Thus, lending by financial institutions occurs more on the basis of operating capital rather than because they are forward looking.

On the internal side, a range of firm-specific characteristics such as degree of innovation, size, export status, organizational form, and quality of human capital emerge as important determinants of external financial access. Innovative firms are more likely to have access; firms that have introduced a new process over the last three years have an 8 percent higher probability of access. Small and medium firms are, respectively, 12.2 and 7.4 percent less likely to have access to external finance compared to large firms, ceteris paribus. Exporters are approximately 8 percent more likely to have access than their counterparts who do not export.

Compared to sole proprietors and partnerships, private limited and publicly listed companies are 3.4 and 5.8 percent more likely to have access, respectively. The quality of human capital, as measured by the top manager's level of education and years of experience, is significantly and positively related to probability of access. The more experienced the top manager of the firm, the higher the chances of access. Moreover firms in which the top manager has a bachelors or a post graduate degree have a greater likelihood of access compared to their counterparts in which the top manager is not a graduate.

To conclude, our results on the determinants of access suggest that, broadly, access to formal credit is a function of two main factors: (i) the availability of infrastructure to provide credit, and (ii) lending organizations' risk perception of the borrower. As far as the former is concerned, there is still limited financial outreach. Even where there is greater financial penetration (in big cities such as Karachi, Lahore, etc.), the financial sector is underdeveloped-evident from the fact that most lending occurs based on operations and turnover and is short-term. Thus, banks evaluate an establishment on the basis of its current financial position as reflected by its accounts or turnover.

In this regard, firm-specific characteristics such as export status, organizational form, and quality of human capital provide important information to banks when deciding whether and how much to lend. Limited companies, for instance, have audited accounts, making it easier for banks to assess the former's financial viability. Exporters may not necessarily have audited accounts but with export receipts coming 
through bank, financial institutions can make well-informed assessments of firms' size and operation. Finally, the quality of human capital is likely to ease interaction and facilitate negotiations with the bank.

Table 5: Determinants of External Financial Access in Pakistan

\begin{tabular}{|c|c|c|}
\hline Variable & Marginal Effect & P Value \\
\hline \multicolumn{3}{|l|}{ External factors } \\
\hline Financial depth & $0.049^{* * *}$ & 0.00 \\
\hline Business climate index & 0.00 & 0.20 \\
\hline Average industry growth & 0.00 & 0.20 \\
\hline \multicolumn{3}{|l|}{ Internal factors } \\
\hline Small & $-0.122^{* * *}$ & 0.00 \\
\hline Medium & $-0.074^{* * *}$ & 0.00 \\
\hline Exporting status & $0.079^{* * *}$ & 0.00 \\
\hline \multicolumn{3}{|l|}{ Organizational form } \\
\hline Privately listed & $0.034^{* *}$ & 0.03 \\
\hline Public limited & $0.058^{* * *}$ & 0.00 \\
\hline \multicolumn{3}{|l|}{ Innovation } \\
\hline New product & -0.04 & 0.19 \\
\hline New process & $0.078^{* *}$ & 0.05 \\
\hline \multicolumn{3}{|l|}{ Human capital } \\
\hline Top manager's experience & $0.002^{* * *}$ & 0.01 \\
\hline Top manager's undergraduate education & $0.135^{* * *}$ & 0.00 \\
\hline Top manager's postgraduate education & $0.196^{* * *}$ & 0.00 \\
\hline \multicolumn{3}{|l|}{ Location dummies $\wedge$} \\
\hline Sheikhupura & $-0.130^{* * *}$ & 0.00 \\
\hline Faisalabad & $-0.117^{* * *}$ & 0.00 \\
\hline Gujranwala & $-0.049^{*}$ & 0.10 \\
\hline Islamabad/Rawalpindi & $-0.107^{* * *}$ & 0.00 \\
\hline Sukkur & $-0.114^{* * *}$ & 0.01 \\
\hline Hyderabad & $-0.078^{*}$ & 0.07 \\
\hline Quetta & $-0.131^{* * *}$ & 0.00 \\
\hline \multicolumn{3}{|l|}{ Industry dummies^ ${ }^{\wedge}$} \\
\hline Chemicals & $0.169^{* * *}$ & 0.01 \\
\hline Leather and leather products & $0.129^{*}$ & 0.07 \\
\hline $\mathrm{N}$ & 1,102 & \\
\hline
\end{tabular}

*** Significant at $1 \%$, ** significant at $5 \%, *$ significant at $10 \%$.

$\wedge$ Only the significant location and industry dummies have been reported.

Source: Authors' calculations. 


\section{Conclusions}

The study's most important conclusion is that finance is a binding constraint to firm growth in Pakistan. Even during the heyday of external finance, manufacturing firms faced an average annual growth penalty of the order of 5.6 percentage points, ceteris paribus. Within the country, access to formal credit is better in cities where there is greater penetration of financial infrastructure. Furthermore, all other firm-specific characteristics such as size, export status, organizational form, and quality of human capital affect growth indirectly through the binding constraint, i.e., access to finance. This is evident from the fact that these variables are statistically significant in the determinants of access regression but insignificant in the growth regressions. These findings shed light on the pivotal role that finance can play in the development of industry and emphasize the need to overcome existing weaknesses in the sector by moving the country toward greater financial development. 


\section{References}

Acemoglu, D., Johnson, S., \& Robinson, J. (2001). The colonial origins of comparative development: An empirical investigation. American Economic Review, 91(5), 1369-1401.

Ayyagari, M., Demirgüç-Kunt, A., \& Maksimovic, V. (2007). Firm innovation in emerging markets: The roles of governance and finance (Policy Research Working Paper No. 4157). Washington, DC: World Bank.

Ayyagari, M., Demirgüç-Kunt, A., \& Maksimovic, V. (2008). How important are financing constraints? The role of finance in the business environment. World Bank Economic Review, 22(3), 483-516.

Beck, T., \& Demirgüç-Kunt, A. (2006). Small and medium-size enterprises: Access to finance as a growth constraint. Journal of Banking and Finance, 30(11), 2931-2943.

Beck, T., Demirgüç-Kunt, A., \& Maksimovic, V. (2005). Financial and legal constraints to growth: Does firm size matter? Journal of Finance, 60(1), 137-177.

Demirgüç-Kunt, A., \& Maksimovic, V. (1998). Law, finance, and firm growth. Journal of Finance, 53(6), 2107-2137.

Goldsmith, R. W. (1969). Financial structure and development. New Haven, CT: Yale University Press.

Government of Pakistan. (2005). Census of manufacturing industries, 2005. Islamabad, Pakistan: Federal Bureau of Statistics.

Government of Pakistan. (2010). Handbook of statistics on Pakistan economy, 2010. Karachi: State Bank of Pakistan.

Guiso, L., Sapienza, P., \& Zingales, L. (2000). The role of social capital in financial development (Unpublished Working Paper No. 7563). Cambridge, MA: National Bureau for Economic Research.

Huang, Y., \& Temple, J. R. W. (2005). Does external trade promote financial development? (Discussion Paper No. 5150). London, UK: Centre for Economic Policy Research. 
Hyytinen, A., \& Toivanen, O. (2005). Do financial constraints hold back innovation and growth? Evidence on the role of public policy. Research Policy, 34, 1385-1403.

King, R. G., \& Levine, R. (1993). Finance and growth: Schumpeter might be right. Quarterly Journal of Economics, 108, 717-738.

La Porta, R., Lopez-de-Silanes, F., Shleifer, A., \& Vishny, R. (1997). The legal determinants of external finance. Journal of Finance, 52, 1131-1150.

La Porta, R., Lopez-de-Silanes, F., Shleifer, A., \& Vishny, R. (1998). Law and finance. Journal of Political Economy, 106, 1113-1155.

Levine, R., \& Zervos, S. (1998). Stock markets, banks, and economic growth. American Economic Review, 88, 537-559.

Lucas, R. E., Jr. (1988). On the mechanics of economic development. Journal of Monetary Economics, 22, 3-42.

Rajan, R. G., \& Zingales, L. (1998). Financial dependence and growth. American Economic Review, 88(3), 559-586.

Rajan, R. G., \& Zingales, L. (2003). The great reversals: The politics of financial development in the twentieth century. Journal of Financial Economics, 69, 5-50.

Robinson, J. (1952). The generalization of the general theory. In The rate of interest and other essays. London, UK: Macmillan.

Schumpeter, J. A. (1911). A theory of economic development. Cambridge, MA: Harvard University Press.

State Bank of Pakistan. (2010). Quarterly performance review of the banking system. Karachi, Pakistan.

Stulz, R. M., \& Williamson, R. (2003). Culture, openness, and finance. Journal of Financial Economics, 70, 313-349.

Wagner, J. (2007). Exports and productivity: A survey of the evidence from firm-level data. The World Economy, 30(1), 60-82.

World Bank. (2009). Pakistan's investment climate: Laying the foundation for renewed growth (Report No. 46435). Islamabad, Pakistan.

World Bank. (2011). World development indicators. 
Annexure A

Table A1: Size Distribution of Firms by Location*

\begin{tabular}{lrcc}
\hline \multicolumn{1}{c}{ City } & Small & Medium & Large \\
\hline Karachi & 8.5 & 19.9 & 43.1 \\
Lahore & 10.1 & 15.4 & 20.4 \\
Sheikhupura & 5.5 & 2.2 & 1.2 \\
Sialkot & 10.2 & 11.5 & 5.8 \\
Faisalabad & 16.2 & 13.8 & 9.2 \\
Gujranwala & 15.3 & 10.4 & 3.1 \\
Wazirabad & 5.8 & 2.0 & 0.4 \\
Islamabad & 7.6 & 7.6 & 6.5 \\
Sukkur & 5.3 & 2.0 & 0.8 \\
Hyderabad & 4.9 & 3.1 & 2.3 \\
Quetta & 6.0 & 1.7 & 1.2 \\
Peshawar & 4.6 & 10.1 & 3.8 \\
Hub & 0.0 & 0.3 & 1.9 \\
\hline
\end{tabular}

*As a percentage of total number of small, medium, and large firms.

Source: Investment Climate Assessment Survey, 2007.

Table A2: Firms with External Financial Access by Location and Size

(\%)

\begin{tabular}{lrrrr}
\hline \multicolumn{1}{c}{ City } & Small & Medium & Large & Total \\
\hline Karachi & 2.1 & 11.3 & 37.5 & 21.9 \\
Lahore & 5.3 & 10.9 & 39.6 & 18.2 \\
Sheikhupura & $0.0^{*}$ & $0.0^{*}$ & 33.3 & 0.6 \\
Sialkot & 13.8 & 17.1 & 46.7 & 16.5 \\
Faisalabad & 0.0 & 10.2 & 25.0 & 9.6 \\
Gujranwala & 10.3 & 21.6 & 37.5 & 24.1 \\
Wazirabad & 12.1 & 14.3 & 0.0 & 6.9 \\
Islamabad & 0.0 & 7.4 & 23.5 & 13.3 \\
Sukkur & 3.3 & 14.3 & 0.0 & 4.7 \\
Hyderabad & 3.6 & 27.3 & 16.7 & 11.9 \\
Quetta & 0.0 & 16.7 & 0.0 & 2.4 \\
Peshawar & 11.5 & 19.4 & 50.0 & 38.5 \\
Hub & $\mathrm{N} / \mathrm{O}^{\wedge}$ & $0.0^{*}$ & 80.0 & 66.7 \\
\hline
\end{tabular}

$\wedge$ No small firms located in Hub.

* There were no firms in this category with access to finance.

Source: Authors' calculations; Investment Climate Assessment Survey, 2007. 
Table A3: Firms with External Financial Access by Industry and Size (Percent)

\begin{tabular}{lrrrr}
\hline \multicolumn{1}{c}{ Category } & Small & Medium & Large & Total \\
\hline Textiles & 4.4 & 14.3 & 27.9 & 12.8 \\
Food & 2.0 & 8.6 & 42.1 & 16.3 \\
Garments & 2.9 & 10.8 & 21.5 & 10.9 \\
Machinery and equipment & 9.3 & 14.3 & 20.0 & 11.9 \\
Chemicals & 0.0 & 22.7 & 66.7 & 28.9 \\
Leather and leather products & 11.1 & 14.3 & 0.0 & 12.5 \\
Electronics & $0.0^{*}$ & $0.0^{*}$ & $0.0^{*}$ & $0.0^{*}$ \\
Nonmetallic minerals & 10.5 & 33.3 & 60.0 & 25.0 \\
Other manufacturing & 6.4 & 13.0 & 36.6 & 13.3 \\
\hline
\end{tabular}

* There were no firms in this category with access to finance.

Source: Authors' calculations; Investment Climate Assessment Survey, 2007. 
Table A4: List and Description of Variables

\begin{tabular}{|c|c|}
\hline Variable & Description \\
\hline Firm growth & $\begin{array}{l}\text { Average annual employment growth rate of the firm } \\
\text { between FY2003 and FY2006. }\end{array}$ \\
\hline $\begin{array}{l}\text { Endogenous measure } \\
\text { of external access }\end{array}$ & $\begin{array}{l}\text { Percentage of working capital financed through } \\
\text { institutional sources, including private commercial } \\
\text { banks, state-owned banks and agencies, and nonbank } \\
\text { financial institutions. }\end{array}$ \\
\hline \multirow[t]{6}{*}{$\begin{array}{l}\text { Instrument for external } \\
\text { financial access }\end{array}$} & $\begin{array}{l}\text { An interaction term between supply- and demand-side } \\
\text { variables. }\end{array}$ \\
\hline & Supply side \\
\hline & $\begin{array}{l}\text { Availability of credit: Measured by number of bank } \\
\text { branches in the city in which firm is located (Banking } \\
\text { Statistics, 2007). }\end{array}$ \\
\hline & $\begin{array}{l}\text { Willingness to provide credit: Measured by percentage of } \\
\text { firms with access to external credit in the firm's } \\
\text { respective size category (Investment Climate } \\
\text { Assessment Survey, 2007). }\end{array}$ \\
\hline & Demand side \\
\hline & $\begin{array}{l}\text { Industry's dependence on external finance: Measured by } \\
\text { bank advances as a ratio of total value added by the } \\
\text { industry (Census of Manufacturing Industries, 2005; } \\
\text { Handbook of Statistics on Pakistan Economy, 2010). }\end{array}$ \\
\hline Small & Dummy $=1$ if firm is small, 0 otherwise. \\
\hline Medium & Dummy = 1 if firm is medium, 0 otherwise. \\
\hline Export status & Dummy $=1$ if firm is an exporting firm, 0 otherwise. \\
\hline \multicolumn{2}{|l|}{ Organizational form } \\
\hline Private limited & $\begin{array}{l}\text { Dummy }=1 \text { if firm is a private limited company, } 0 \\
\text { otherwise. }\end{array}$ \\
\hline Publicly listed & $\begin{array}{l}\text { Dummy }=1 \text { if firm is a publicly listed company, } 0 \\
\text { otherwise. }\end{array}$ \\
\hline \multicolumn{2}{|l|}{ Innovation } \\
\hline New process & $\begin{array}{l}\text { Dummy }=1 \text { if firm has introduced a new process } \\
\text { during the last three years, } 0 \text { otherwise. }\end{array}$ \\
\hline New product & $\begin{array}{l}\text { Dummy = } 1 \text { if firm has introduced a new product } \\
\text { during the last three years, } 0 \text { otherwise. }\end{array}$ \\
\hline
\end{tabular}


Human capital

Experience

Number of years the top manager has been in the field.

Undergraduate degree Dummy $=1$ if the top manager has a BA degree, 0 otherwise.

Postgraduate degree Dummy $=1$ if the top manager has a postgraduate (local or foreign) degree, 0 otherwise.

Education of a typical Dummy $=1$ if a typical production worker has more production worker than 13 years of education, 0 otherwise.

Business climate index

A simple average of 13 different dimensions of the business environment. Responses are based on manager's perception of how much of a constraint each of these factors is in firm's operations and growth.

The various dimensions include: access to land, power, telecommunications, water supply, crime/theft, transportation, tax administration, tax regulation, licensing and permits, macroeconomic instability, political instability, corruption, labor regulations.

Location dummies

Lahore

Dummy $=1$ if firm is located in Lahore, 0 otherwise.

Sheikhupura

Dummy = 1 if firm is located in Sheikhupura, 0 otherwise.

Sialkot

Dummy $=1$ if firm is located in Sialkot, 0 otherwise.

Faisalabad

Dummy = 1 if firm is located in Faisalabad, 0 otherwise.

Gujranwala

Dummy = 1 if firm is located in Gujranwala, 0 otherwise.

Wazirabad

Dummy $=1$ if firm is located in Wazirabad, 0 otherwise.

Islamabad/

Dummy $=1$ if firm is located in

Rawalpindi Islamabad/Rawalpindi, 0 otherwise.

Sukkur

Dummy = 1 if firm is located in Sukkur, 0 otherwise.

Hyderabad

Dummy $=1$ if firm is located in Hyderabad, 0 otherwise.

Quetta

Dummy $=1$ if firm is located in Quetta, 0 otherwise.

Peshawar

Dummy = 1 if firm is located in Peshawar, 0 otherwise.

$\mathrm{Hub}$

Dummy = 1 if firm is located in Hub, 0 otherwise.

Industry dummies

Garments

Dummy $=1$ if firm falls in this industry, 0 otherwise. 
Textiles Dummy $=1$ if firm falls in this industry, 0 otherwise.

Machinery and Dummy $=1$ if firm falls in this industry, 0 otherwise. equipment

Chemicals

Dummy $=1$ if firm falls in this industry, 0 otherwise.

Electronics

Dummy $=1$ if firm falls in this industry, 0 otherwise.

Nonmetallic minerals

Dummy $=1$ if firm falls in this industry, 0 otherwise.

Leather and leather

Dummy $=1$ if firm falls in this industry, 0 otherwise.

products 